\title{
Lignan and isoflavonoid concentrations in tea and coffee
}

\author{
W. M. Mazur ${ }^{1}$, K. Wähälä ${ }^{2}$, S. Rasku ${ }^{2}$, A. Salakka ${ }^{2}$, T. Hase ${ }^{2}$ and H. Adlercreutz ${ }^{1} *$ \\ ${ }^{1}$ Department of Clinical Chemistry, University of Helsinki and Folkhälsan Research Center, PO Box 60, \\ FIN-00014 Helsinki, Finland \\ ${ }^{2}$ Department of Chemistry, PO Box 55, FIN-00014 Helsinki, Finland
}

(Received 14 January 1997 - Revised 25 June 1997 - Accepted 14 July 1997)

\begin{abstract}
Tea is a beverage consumed widely throughout the world. The existence in tea of chemopreventing compounds possessing antimutagenic, anticarcinogenic and antioxidative properties has been reported. High intakes of tea and foods containing flavonoids have recently been shown to be negatively correlated to the occurrence of CHD. However, tea may contain other compounds with similar activities. Using a new gas chromatographic-mass spectrometric method we measured lignans and isoflavonoids in samples of twenty commercial teas (black, green and red varieties) and, for comparison, six coffees. Both unbrewed and brewed tea were investigated. The analysis of the teas yielded relatively high levels of the lignans secoisolariciresinol $(5.6-28.9 \mathrm{mg} / \mathrm{kg} ; 15.9-81.9 \mu \mathrm{mol} / \mathrm{kg})$ and matairesinol $(0.56-4.13 \mathrm{mg} / \mathrm{kg}$; $1.6-11.5 \mu \mathrm{mol} / \mathrm{kg}$ ) but only low levels of isoflavonoids. Because the plant lignans, as well as their mammalian metabolites enterolactone and enterodiol, have antioxidative properties and these mammalian lignans occur in high concentrations in plasma, we hypothesize that lignan polyphenols may contribute to the protective effect of tea on CHD.
\end{abstract}

Tea: Coffee: Phyto-oestrogens: Lignans

Of 2.5 million cubic tons of tea leaves manufactured in the world annually, about $78 \%$ is used for the preparation of black tea, which is mainly consumed in Western countries, and about $20 \%$ is used for the preparation of green tea, which is mainly consumed in Asian countries and in some parts of North Africa (Graham, 1992). The fresh tea leaves are blanched and twisted. On drying, the result of this process is green tea. This tea contains polyphenols such as flavanols (catechins), flavonols, flavonediols, and phenolic acids. These polyphenols account for $25-30 \%$ of the solids in water extract of green tea leaves. On the other hand, if chopped and rolled tea leaves are allowed to wither for about $6 \mathrm{~h}$, the polyphenols become oxidized by an enzyme, polyphenol oxidase, and the result is black tea containing bisflavonols, theaflavins, thearubigens, and other oligomers. The process is called 'tea fermentation'. The intermediate treatment of enzymic oxidation for $1-2 \mathrm{~h}$ yields Oolong tea favoured in Taiwan and parts of China.

In recent years it has become clear that dietary practice and other aspects of lifestyle play an important role in determination of the risk for development of a number of major human cancers and chronic diseases such as CHD. Since tea (Camellia sinensis) is one of the most popular beverages consumed worldwide, knowledge about composition and health effects of tea drinking has important implications. Epidemiological studies show that individuals consuming four or more cups of tea per day have a lower risk of atherosclerosis and CHD (Green \& Harari, 1992; Kono, 1992; Stensvold et al. 1992; Imai \& Nakachi, 1995). Other investigators have investigated tea and coffee with regard to non-nutritional components (chemopreventers) possessing antimutagenic, anticarcinogenic and antioxidative properties and studies have been conducted in order to explore associations between tea consumption or tea compounds, and human cancers at different sites (Young et al. 1967; Jain et al. 1989; Wang et al. 1989; Ho et al. 1992; Mukhtar et al. 1992; Stich, 1992; Nanjo et al. 1993; Yoshino et al. 1994; Hu et al. 1995; Sano et al. 1995; Vinson et al. 1995; Katiyar \& Mukhtar, 1996). The major part of the experimental research has dealt with the anticarcinogenic properties of green tea extracts and their major constituents (Gao et al. 1994) and few in vitro

\footnotetext{
Abbreviations: AnhSECO, anhydrosecoisolariciresinol; END, enterodiol; ENL, enterolactone; GC-MS, gas chromatography-mass spectrometry; MAT, matairesinol; SECO, secoisolariciresinol.

*Corresponding author: Professor Herman Adlercreutz, fax +358 961585 633; email herman.adlercreutz@helsinki.fi
} 
studies have dealt with black tea theaflavins and thearubigin. Results from laboratories are in general full of promise and show inhibitory effects of tea against tumourigenesis using cultured mammalian cancer cells or experimental animal models (Katiyar et al. 1992; Klaunig, 1992; Wang et al. 1992, 1994; Hirose et al. 1993; Hu et al. 1995). However, in contrast, epidemiological studies have so far yielded inconclusive results (Heilbrun et al. 1986; Kinlen $e t$ al. 1988; La Vecchia et al. 1992; Brown et al. 1993; Goldbohm et al. 1996). With regard to tea and cancer (Kohlmeier et al. 1997) a recent survey of the epidemiological literature also shows an inconsistent picture. The studies on tea and lung, stomach, colon or rectal cancer do not suggest a protective role for tea drinking. Other reports suggest an increased risk with increased tea consumption. However, these data do not encompass epidemiological studies of hormone-dependent cancers (uterus, breast and prostate cancers) which, due to their aetiology, could be affected by phyto-oestrogens.

The epidemiological associations referring to beneficial effects of drinking tea with regard to serum cholesterol, serum lipids, blood pressure and finally CHD were found in human studies, two in Japan (Kono, 1992; Imai \& Nakachi, 1995), one in Israel (Green \& Harari, 1992) and the other one in Norway (Stensvold et al. 1992). Tea consumption is particularly high in Japan and some other Asian countries with low incidence of and mortality from this disease. In Asia CHD mortality is only about one tenth of that in European countries (Stehle et al. 1991).

Recently tea flavonoids (the flavonols quercetin, kaempferol, myricetin, and the flavones apigenin, and luteolin) have been found and measured in tea extracts (Hertog et al. $1993 b$ ). In a prospective study in Dutch men it was shown that high intake of flavonoids in food was significantly inversely associated with mortality from CHD (Hertog et al. 1993a). The major sources of flavonoids were tea $(61 \%)$, onions $(13 \%)$ and apples $(10 \%)$.

In the present study we show for the first time the presence of the lignans matairesinol (MAT) and secoisolariciresinol (SECO) in black and green tea, as well as in coffee. Small amounts of isoflavonoids were also detected.

\section{Materials and methods}

\section{Sources of beverages}

All tea and coffee samples analysed here were purchased from a supermarket. Typical types of English black tea were included as well as several brands of green tea of which consumption nowadays has become more and more popular in Western countries. Before weighing, the dry tea leaves were ground with an electric grinder.

\section{Chemicals and standards}

All chemicals and details of the synthesis of standards have been presented in a publication describing an isotope dilution gas chromatographic-mass spectrometric (GCMS) method for the determination of lignans and isoflavonoids in food samples (Mazur et al. 1996) as well as in two earlier publications on GC method for lignans and a GC-MS method for the oestrogen profile in human urine (Fotsis \& Adlercreutz, 1987; Adlercreutz et al. 1991). All glassware including Pasteur pipettes used for ion-exchange chromatography and the glass liner of the injection system of the GC-MS instruments (HP 5995 quadrupole mass spectrometer with Autoinjector 7673A and data system HP 59970C MS Chem Station; Hewlett Packard OY, Espoo, Finland) was deactivated by silanization with dimethyl-<smiles>O=c1c(-c2ccc(O)cc2)coc2cc(O)ccc12</smiles>

Daidzein<smiles>COc1ccc(-c2coc3cc(O)ccc3c2=O)cc1</smiles>

Formononetin<smiles>O=c1c(-c2ccc(O)cc2)coc2cc(O)cc(O)c12</smiles>

Genistein<smiles>COc1ccc(-c2coc3cc(O)cc(O)c3c2=O)cc1</smiles>

Biochanin A<smiles>O=c1oc2cc(O)ccc2c2oc3cc(O)ccc3c12</smiles>

Coumestrol<smiles>COc1cc(CC2COC(=O)C2Cc2ccc(O)c(OC)c2)ccc1O</smiles>

Matairesinol<smiles>COc1cc(CC(CO)C(CO)Cc2ccc(O)c(OC)c2)ccc1O</smiles>

Secoisolariciresinol

Fig. 1. The detected and measured phyto-oestrogens in tea and coffee. 


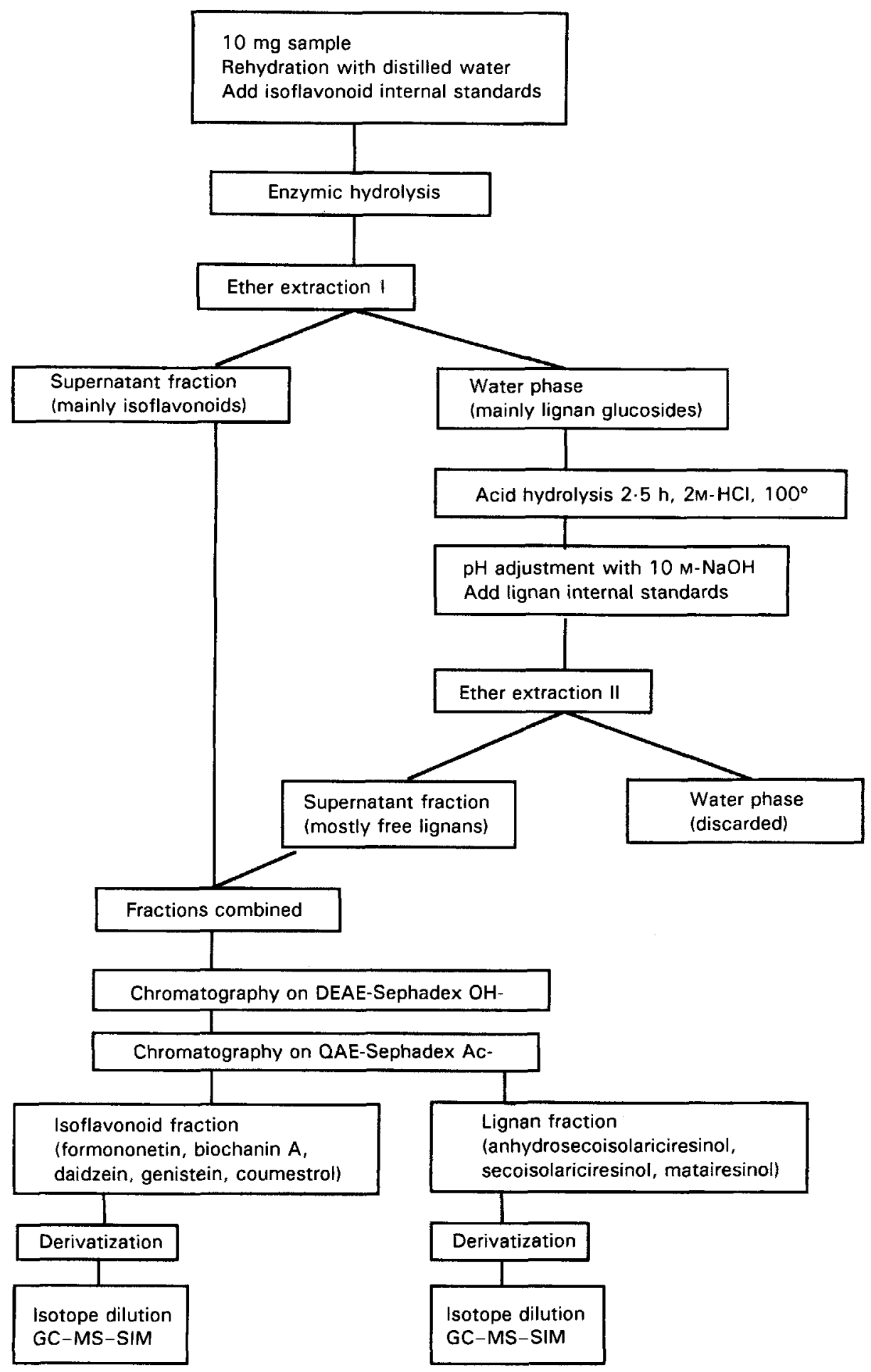

Fig. 2. Flow-diagram of the method for the determination of lignans and isoflavonoids in tea and coffee samples. DEAE, diethylaminoethyl; QAE, quaternary aminoethyl; GC-MS-SIM, gas chromatography-mass spectrometry in the selected ion monitoring mode.

chlorosilane in toluene $(10 \mathrm{ml} / \mathrm{l})$ or Siliconimprägnierer (Carl Roth GmbH, Karlsruhe, Germany).

\section{Analytical methods}

GC-MS method for the determination of lignans and isoflavonoids (Fig. 1) in meals and freeze-dried foods, described in detail previously, including studies on its reliability, was applied with slight modifications in the tea assays. Two types of experiment were carried out to test the accuracy of the method. The mean recoveries of authentic reference standards added to water ( $n$ 20), taken through the whole procedure, were found to be very close to $100 \%$, and the measurements showed good precision. In other 
experiments ( $n$ 10) standards were added to a meal with relatively low phyto-oestrogen concentration and the mean recovery for all the analysed phyto-oestrogens was $99.5 \%$. The sensitivity limit of the method was approximately $0.02-0.03 \mathrm{mg} / \mathrm{kg}$ (standard deviation of multiple assays at low levels multiplied by 2 or 3 ). The $\mathrm{CV}$ for the method used was found to vary between 3.1 and 9.6 (concentration range $0.045-1.32 \mathrm{mg} / \mathrm{kg}$ ) for the seven compounds measured (Mazur et al. 1996). The method is shown in Fig. 2 and is described briefly here.

Expt 1. To $10 \mathrm{mg}$ powdered tea from commercial sources $500 \mu$ ionized water was added and the sample allowed to stand overnight. Synthesized deuterated internal standards of isoflavonoids were added (for structures, see Mazur et al. 1996) and the sample was hydrolysed with an extract from Helix pomatia $(25 \mu \mathrm{l}$, 2500 Fishman units). After ethyl ether extraction and separation of the phases, the ether phase (mainly isoflavonoids) was evaporated and preserved in methanol at $-20^{\circ}$ until combined with the fraction containing mainly lignans. The ether in the water phase was evaporated and this was followed by $\mathrm{HCl}$ hydrolysis (mainly of lignan conjugates). Next the hydrolysate was brought to $\mathrm{pH} 3-5$ with $\mathrm{NaOH}$ and synthesized deuterium-labelled SECO, anhydrosecoisolariciresinol (AnhSECO) and MAT were added. The addition of AnhSECO was necessary because the acid hydrolysis converts quantitatively most of the SECO present to this compound. The water-phase was then extracted with ethyl ether as described and the ether evaporated to dryness. This fraction, containing mainly lignans, was combined with the isoflavonoid fraction in methanol. The sample was then submitted to ion-exchange chromatographies as described previously (Adlercreutz et al. 1991). The separated lignan and isoflavonoid fractions were converted to trimethylsilyl ethers (Adlercreutz et al. 1991) and the compounds were quantitatively measured using isotope dilution capillary GC-MS in the selected ion monitoring mode as described previously (Adlercreutz et al. 1991; Mazur et al. 1996). The following compounds were quantified: MAT, SECO, anhSECO, formononetin, daidzein, biochanin A, genistein, coumestrol. The SECO results are presented as the sum of SECO and AnhSECO. All assays were carried out in duplicate or quadruplicate.

To test whether a traditional way of brewing tea releases the phyto-oestrogens into the water a second experiment was performed.

Expt 2. To $200 \mathrm{mg}$ of each sample in a tube $10 \mathrm{ml}$ boiling distilled water was added. The tubes were kept in a water-bath $\left(90-95^{\circ}\right)$ for $10 \mathrm{~min}$ in order to brew the tea. When the process was completed $500 \mu \mathrm{l}$ infusion was transferred into a dry tube. After adding the synthesized deuterated internal standards of the isoflavonoids the sample was subjected to enzyme hydrolysis and the subsequent steps were identical with those in Expt 1.

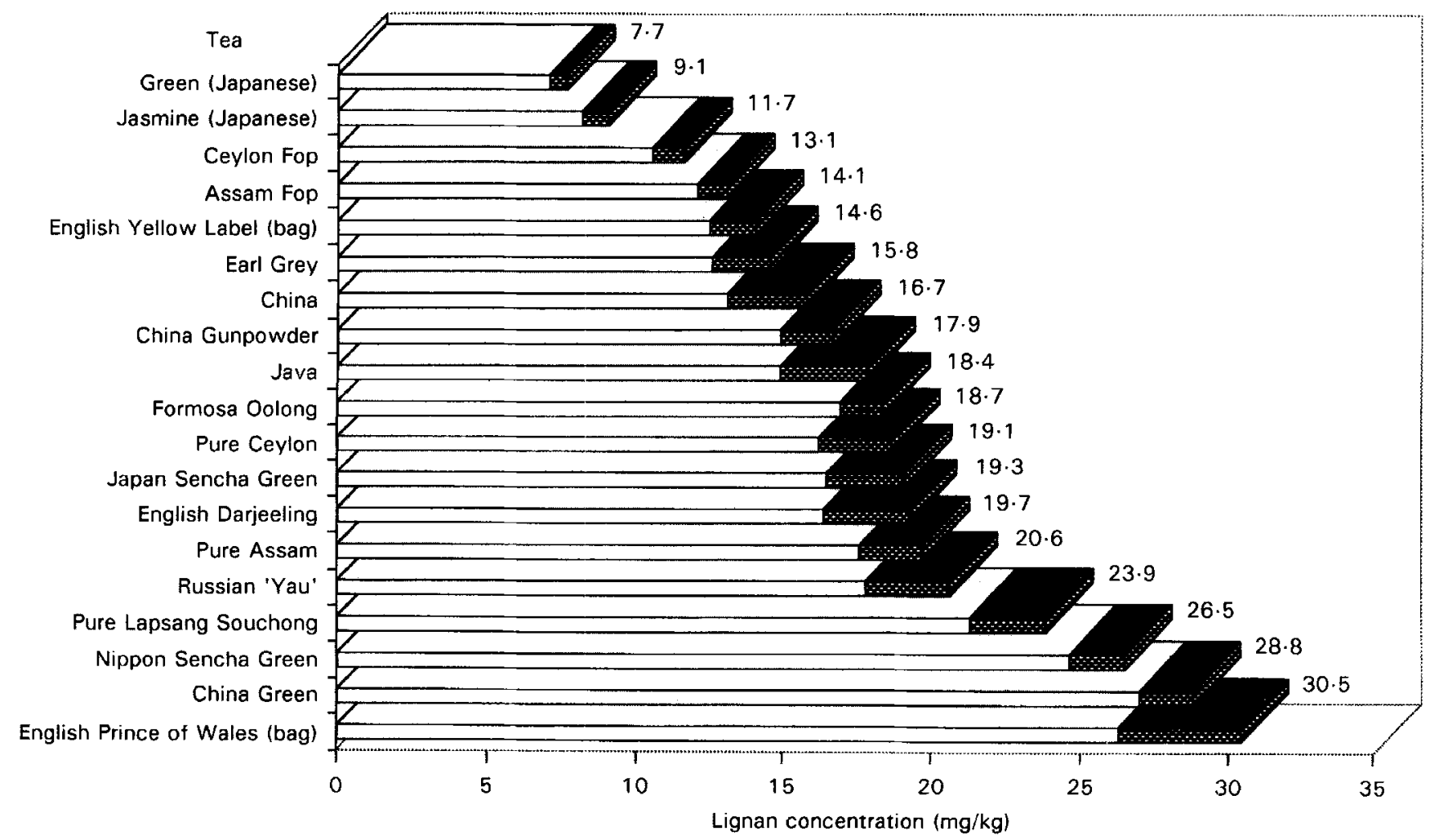

Fig. 3. Expt 1. Total lignan concentrations (secoisolariciresinol $(\square)+$ matairesinol $(\square)$ ) in tea samples (leaves + infusion). 
Table 1. Expts 1 and 2. Concentrations of secoisolariciresinol (SECO) and matairesinol (MAT) in teas and coffees

\begin{tabular}{|c|c|c|c|c|}
\hline \multirow[b]{2}{*}{ Brand, origin and supplier } & \multicolumn{2}{|c|}{$\begin{array}{l}\text { Expt } 1 \\
\text { Tea leaves and coffee meal processed } \\
\text { according to the method }\end{array}$} & \multicolumn{2}{|c|}{$\begin{array}{l}\text { Expt } 2 \\
\text { Tea brewed and only the aqueous } \\
\text { infusion analysed }\end{array}$} \\
\hline & SECO $(\mathrm{mg} / \mathrm{kg})^{*}$ & MAT (mg/kg) & SECO $(\mathrm{mg} / \mathrm{kg})^{*}$ & MAT $(\mathrm{mg} / \mathrm{kg})$ \\
\hline $\begin{array}{l}\text { Pure Lapsang Souchong tea (China) } \\
\text { Jacksons of Piccadilly, England }\end{array}$ & 21.30 & 2.50 & 10.50 & 0.90 \\
\hline $\begin{array}{l}\text { Pure Assam tea (North-East India) } \\
\text { Jacksons of Piccadilly, England }\end{array}$ & 17.60 & 2.09 & - & - \\
\hline $\begin{array}{l}\text { Earl Grey tea (Oriental tea mixture) } \dagger \\
\text { Lipton, England }\end{array}$ & 12.59 & 1.97 & $16 \cdot 50$ & 1.06 \\
\hline $\begin{array}{l}\text { China tea (China) } \dagger \\
\text { Lipton, England }\end{array}$ & $13 \cdot 10$ & 2.69 & - & - \\
\hline $\begin{array}{l}\text { Yellow label tea-bag (not known) } \\
\text { Lipton, England }\end{array}$ & 12.50 & 1.57 & 10.92 & 0.92 \\
\hline $\begin{array}{l}\text { Darjeeling tea (Himalayan mountains, North-East India) } \\
\text { Twinings, England } \dagger\end{array}$ & 16.40 & 2.88 & - & - \\
\hline $\begin{array}{l}\text { Java tea (Java) } \\
\quad \text { Kloth \& Köhuken GmbH, Germany }\end{array}$ & 14.90 & 2.95 & - & - \\
\hline $\begin{array}{l}\text { Russian 'Yau' tea (Russia) } \\
\text { Kloth \& Köhuken GmbH, Germany }\end{array}$ & 17.80 & 2.83 & - & - \\
\hline $\begin{array}{l}\text { Prince of Wales, tea-bag (not known) } \dagger \\
\text { Twinings, England }\end{array}$ & $26 \cdot 32$ & $4 \cdot 13$ & 24.18 & 3.05 \\
\hline $\begin{array}{l}\text { Pure Ceylon tea (Sri Lanka) } \dagger \\
\text { Jacksons of Piccadilly, England }\end{array}$ & $16 \cdot 20$ & 2.48 & - & - \\
\hline $\begin{array}{l}\text { Assam Fop (India) } \\
\text { Nordqvist, Finland }\end{array}$ & $12 \cdot 10$ & 0.99 & 10.34 & 0.71 \\
\hline $\begin{array}{l}\text { Ceylon Fop (Sri Lanka) } \ddagger \\
\text { Nordquist, Finland }\end{array}$ & 10.59 & 1.06 & - & - \\
\hline Mean & $15.93(\mathrm{SD} 3.35)$ & 2.35 (SD 0.68) & 13.88 (SD 4.31) & 1.38 (SD 0.75) \\
\hline $\begin{array}{l}\text { Formosa Oolong-red tea } \ddagger \\
\text { Nordqvist, Finland }\end{array}$ & 16.93 & 1.43 & 13.94 & 0.88 \\
\hline $\begin{array}{l}\text { Jasmine tea (not known) } \uparrow \S \Upsilon^{\star \star} \\
\text { Twinings, England }\end{array}$ & 8.22 & 0.87 & 6.71 & 0.71 \\
\hline $\begin{array}{l}\text { Green tea (Japan) }+\S \pi+\dagger \\
\text { Unknown }\end{array}$ & $7 \cdot 11$ & 0.59 & 6.09 & 0.56 \\
\hline $\begin{array}{l}\text { China Green tea } \\
\text { Nordqvist, Finland }\end{array}$ & 27.02 & 1.81 & 28.87 & 1.95 \\
\hline $\begin{array}{l}\text { Nippon Sencha Green tea } \\
\text { Nordqvist, Finland }\end{array}$ & 24.66 & 1.86 & 27.01 & 2.12 \\
\hline $\begin{array}{l}\text { China Gunpowder: } \\
\text { Nordqvist, Finland }\end{array}$ & 14.91 & 1.78 & 17.94 & 2.09 \\
\hline $\begin{array}{l}\text { Japan Sencha Green tea } \\
\text { Nordqvist, Finland }\end{array}$ & $16 \cdot 48$ & $2 \cdot 63$ & 18.87 & 2.77 \\
\hline Mean & 16.40 (SD 6.32) & $1.59(S D 0.57)$ & $17.40($ SD 7.70$)$ & $1.70(\mathrm{SD} 0.71)$ \\
\hline $\begin{array}{l}\text { Nescafé, instant coffee (Arabica) } \\
\text { Nestlé S.A., Switzerland }\end{array}$ & 7.16 & ND & - & - \\
\hline $\begin{array}{l}\text { Kafe Hag coffee (Blend) } \dagger \\
\text { Hag GF AG, Bremen, Germany }\end{array}$ & 5.35 & ND & - & - \\
\hline $\begin{array}{l}\text { Guatemala coffee (Guatemala)\| } \\
\text { Paulig Oy, Finland }\end{array}$ & 5.08 & ND & - & - \\
\hline $\begin{array}{l}\text { Cellini expresso coffee (Blend) } \S \\
\text { EKAF-industria nazionale del caffé } 65 ., \text { Genova, Italy }\end{array}$ & 7.14 & ND & - & - \\
\hline $\begin{array}{l}\text { Mövenpick coffee (South American blend)\& } \| \\
\text { Mövenpick, AG, Switzerland }\end{array}$ & 3.93 & ND & - & - \\
\hline $\begin{array}{l}\text { Maxwell coffee (Java)\| } \\
\quad \text { Maxwell Kraft GF, Banbury, England }\end{array}$ & 5.01 & ND & - & - \\
\hline Mean & 5.61 (SD 1.03) & - & & \\
\hline
\end{tabular}

ND, not determined due to low concentration (below a detection limit) and interferences by other compounds.

"All the values given in $\mathrm{mg} / \mathrm{kg}$ dry leaves or grains.

† Expt 1: additionally contained concentrations of the isoflavonoid daidzein ranging from 0.1 to $0.66 \mathrm{mg} / \mathrm{kg}$.

Expt 1: additionally contained concentrations of the isoflavonoid biochanin A ranging from 0.05 to $0.19 \mathrm{mg} / \mathrm{kg}$.

\& Expt 1: additionally contained concentrations of the isoflavonoid genistein ranging from 0.15 to $0.29 \mathrm{mg} / \mathrm{kg}$.

II Expt 1: additionally contained concentrations of the isflavonoid formononetin ranging from 0.72 to $0.78 \mathrm{mg} / \mathrm{kg}$.

1. Expt 1: additionally contained coumestrol concentrations of $0.33 \mathrm{mg} / \mathrm{kg}$ (Jasmine tea) and 0.42 (Green tea) $\mathrm{mg} / \mathrm{kg}$.

** Expt 2: additionally contained daidzein, genistein and coumestrol concentrations of $0.11,0.34$ and $0.29 \mathrm{mg} / \mathrm{kg}$ respectively.

† Expt 2: additionally contained daidzein, genistein and coumestrol concentrations of $0.1,0.35$ and $0.32 \mathrm{mg} / \mathrm{kg}$ respectively. 


\section{Results}

The individual lignan results for thirteen black teas commercially available in Finland, six green teas, one red Oolong tea and for comparison six samples of coffee, are shown in Table 1. The total lignan values are shown in Fig. 3. In parallel the results after brewing are shown in Table 1.

For some of the tea samples, brewing in hot water as the first step of the method was employed (Expt 2). The most important observation is that the lignans were almost quantitatively liberated by this process into the water from the green teas, but only partly from the black teas. For five of seven black teas analysed in Expt 2 brewing yielded slightly lower levels of SECO, but considerably lower amounts of MAT compared with the amounts in the leaves. An agreement between lignan contents measured in Expts 1 and 2 was also found for the red Oolong tea (Expt 1: $16.93 \mathrm{mg} / \mathrm{kg}(48.0 \mu \mathrm{mol} / \mathrm{kg})$ and $1.43 \mathrm{mg} / \mathrm{kg}(4.0 \mu \mathrm{mol} / \mathrm{kg})$; Expt 2: $13.94 \mathrm{mg} / \mathrm{kg} \quad(39.5 \mu \mathrm{mol} / \mathrm{kg})$ and $0.9 \mathrm{mg} / \mathrm{kg}$ $(2.5 \mu \mathrm{mol} / \mathrm{kg})$ of $\mathrm{SECO}$ and MAT respectively). In the brewed Earl Grey tea sample SECO was higher than measured in the tea leaves (MAT concentration remained unchanged after brewing) and in Ceylon Fop SECO concentrations were the same before and after brewing (MAT level lower).

In Expt 1 lignans in tea leaves were analysed by the original procedure (Mazur et al. 1996). This method included, in addition to soaking with distilled water at room temperature overnight, enzymic $\left(60^{\circ}, 2 \mathrm{~h}\right)$ and acid $\left(2 \mathrm{M}-\mathrm{HCl}, 2.5 \mathrm{~h}, 100^{\circ}\right)$ hydrolysis. These conditions in principle should lead to higher yield than simple brewing of the tea (Expt 2) after which leaves were discarded and the brewage (aqueous infusion) taken through the hydrolytic procedures. Results of Expts 1 and 2 (Table 1, Fig. 3) for the black teas suggest that the tea fermentation process may decrease the accessibility of tea polyphenols during brewing. The mean concentrations of SECO and MAT respectively for all the black teas analysed in Expt 1 were 15.93 (SD 3.35) $\mathrm{mg} / \mathrm{kg}(45.1$ (SD 9.5) $\mu \mathrm{mol} / \mathrm{kg}$ ) and 2.35 (SD 0.68) $\mathrm{mg} / \mathrm{kg}(6.6$ (SD 1.9) $\mu \mathrm{mol} / \mathrm{kg}$ ). The mean values for the five teas brewed in Expt 2 were 13.9 (SD 4.31) mg/ $\mathrm{kg}(39.4$ (SD 12.2) $\mu \mathrm{mol} / \mathrm{kg}$ ) of SECO and 1.38 (SD 0.75) $\mathrm{mg} / \mathrm{kg}(3.9$ (SD 2.1) $\mu \mathrm{mol} / \mathrm{kg}$ ) of MAT. Mean values for SECO and MAT for all the green teas (Expt 1) were 16.40 (SD 6.32) $\mathrm{mg} / \mathrm{kg}(46.5$ (SD 17.9) $\mu \mathrm{mol} / \mathrm{kg}$ ) and 1.59 (SD $0.57) \mathrm{mg} / \mathrm{kg}$; (4.4 (SD 1.6) $\mu \mathrm{mol} / \mathrm{kg}$ ) respectively. All the green teas brewed, except one Japanese tea of unknown source and Jasmine tea (green tea scented with jasmine flowers), gave slightly higher values for both SECO (mean value 17.40 (SD 7.70) $\mathrm{mg} / \mathrm{kg}(49.3$ (SD 21.8) $\mu \mathrm{mol} / \mathrm{kg})$ ) and MAT (mean value 1.70 (SD 0.71 ) $\mathrm{mg} / \mathrm{kg}$ (4.7 (SD 2.0) $\mu \mathrm{mol} / \mathrm{kg})$ ) than the same ones processed by the original method. It is conceivable that the Jasmine tea was of the same origin as the Japanese green tea as indicated by similar contents of lignan and isoflavonoids found in these two teas. These teas are also the only ones for which brewing yielded measurable amounts of daidzein, genistein and coumestrol (Table 1). Small amounts of daidzein, ranging from 0.1 to $0.66 \mathrm{mg} / \mathrm{kg}(0.4-2.6 \mu \mathrm{mol} / \mathrm{kg})$, were quantitatively determined (Expt 1) in black (Earl Grey, China, Darjeeling, Java, Prince of Wales, Pure Ceylon) and
Formosa Oolong-red tea samples; the others had daidzein present in traces. By comparison in three coffee samples (Guatemala, Mövenpick and Maxwell coffee) formononetin was found in concentrations between 0.7 and $0.85 \mathrm{mg} /$ $\mathrm{kg}(2 \cdot 6-3 \cdot 2 \mu \mathrm{mol} / \mathrm{kg})$ of coffee. None of the isoflavonoids in the black tea and in most of the green tea samples brewed in Expt 2 was measurable with our technique, mainly due to their low concentration and some interfering compounds at these very low levels.

\section{Discussion}

All the major constituents (e.g. flavonols, flavanols and phenols), detected in tea until now, have been studied with respect to their anticancer, antimutagenic and antioxidative activities (Jain et al. 1989; Wang et al. 1989; Ho et al. 1992; Mukhtar et al. 1992; Stich, 1992; Yoshino et al. 1994; Hu et al. 1995; Sano et al. 1995; Vinson et al. 1995; Katiyar \& Mukhtar, 1996). However, the mechanisms by which such effects are induced in vivo are largely unknown. It remains to be seen whether those properties are related to these compounds or some new ones in tea leaves, for instance lignans, or a concerted action of all polyphenols. When ingested the plant lignans MAT and SECO undergo metabolic conversions in the intestine resulting in the formation of hormone-like compounds with weak oestrogenic activity and the ability to bind weakly to oestrogen receptors (Adlercreutz \& Mazur, 1997). MAT is altered by gut bacteria to enterolactone (ENL) and SECO to enterodiol (END) and then END is oxidized to ENL. In vitro studies (Jordan et al. 1985) have demonstrated oestrogenic properties of these mammalian lignans (ENL and END) in tissue cultures in the absence of oestradiol. But a slightly stimulatory or non-stimulatory concentration of oestradiol combined with a slightly stimulatory concentration of ENL did not cause any stimulation or a tendency to inhibition of $\mathrm{MCF}-7$ breast cancer cells (Mousavi \& Adlercreutz, 1992). Two in vivo studies, one in rats (Waters \& Knowler, 1982) and the other in mice (Setchell et al. 1981), yielded divergent results. These levels of lignans are probably too low to have any measurable oestrogenic effects in man as judged from some in vitro studies (Welshons et al. 1987) but antioestrogenic effects cannot be excluded. In any case, tea probably contributes to plasma ENL levels in man. The concentration of SECO in tea $(15.9-81.9 \mu \mathrm{mol} / \mathrm{kg})$ is much higher than in plasma $(0-4.3 \mathrm{nmol} / 1$; H Adlercreutz, unpublished results) and over 1000 times higher than that of plasma ENL $(2.7-54.4 \mathrm{nmol} / \mathrm{l})$ in Finnish subjects $(\mathrm{H}$ Adlercreutz, unpublished results).

Tea contains numerous polyphenols, which may have both beneficial and hazardous effects. Some of these occur in concentrations far higher (like gallic acid, $640 \mathrm{mg} / \mathrm{kg}$ and caffeic acid, $250 \mathrm{mg} / \mathrm{kg}$; Horvat \& Senter, 1980) than the lignans shown in Table 1 . The concentrations of flavonols in tea are even higher (quercetin $2400-2880 \mathrm{mg} / \mathrm{kg}(7.95-$ $9.07 \mathrm{mmol} / \mathrm{kg}$ ) and kaempferol $1630-2130 \mathrm{mg} / \mathrm{kg}(5.70$ $7.45 \mathrm{mmol} / \mathrm{kg}$ )) (Hertog et al. 1993b) and one would therefore expect that they occur in high concentrations in biological fluids. The problem is that specific quantitative 
data regarding concentrations of the food compounds in human biological fluids are scanty. Absorption and excretion have been studied only for the flavonol quercetin and its glycosides (Gugler et al. 1975; Hollman et al. 1995; Paganga \& Rice-Evans, 1997) but the first precise measurements of quercetin glycosides in plasma were reported very recently (Hollman et al. 1996). In contrast, the lignans and isoflavonoids have been found to occur in high concentrations in plasma and urine (Adlercreutz et al. $1982,1993 b$ ) and have been quantitatively determined in human saliva, breast aspirate, cyst and prostatic fluid (Finlay et al. 1991; Morton et al. 1997). Recently, Hollman et al. (1995) studied absorption and urinary excretion of dietary quercetin glycosides and quercetin in healthy ileostomy volunteers and found that significant amounts of quercetin glycoside present in experimental diets were absorbed by the human small intestine; however, no quantitative measurements in plasma were shown. Absorption of quercetin rutinoside, the major quercetin compound in tea, amounted to $17 \%$. Recently the same group (Hollman et al. 1996) reported plasma quercetin concentrations in two subjects after ingestion of fried onions. A meal supplemented with quercetin glycosides equivalent to $64 \mathrm{mg}$ quercetine aglycone reached peak plasma levels of $196 \mathrm{ng} / \mathrm{ml}(649 \mathrm{nmol} / \mathrm{l})$ after $2.9 \mathrm{~h}$. After $48 \mathrm{~h}$ the plasma concentration was about $10 \mathrm{ng} / \mathrm{ml}(33 \mathrm{nmol} / \mathrm{l})$.

Plasma and urinary levels of tea catechins in human subjects have been reported (Lee et al. 1995). After ingestion of $1.2 \mathrm{~g}$ decaffeinated green tea infused in warm water, plasma concentrations ranges were $46-268 \mathrm{ng} / \mathrm{ml}$ (104-606 nmol/1) (-)-epigallocatechin-3-gallate, 82-206 $\mathrm{ng} / \mathrm{ml}(268-673 \mathrm{nmol} / \mathrm{l})(-)$-epigallocatechin and 48-80

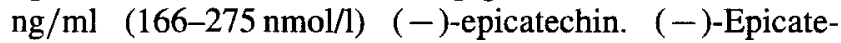
chin-3-gallate was not detected in plasma samples. The total amount of the catechins excreted was approximately $5 \mathrm{mg}$, accounting for $2 \%$ total polyphenols ingested. In the case of black tea, containing $10-37 \%$ of the catechins present in green tea, these amounts would be significantly less.

There are no studies reporting concentrations of the lignans in human biological fluids after consumption of tea or coffee. The measurements of ENL and END levels in human urine and plasma have been performed. In one of our previous studies the mean value of total ENL + END concentration in the plasma of vegetarians was $80.5 \mathrm{ng} / \mathrm{ml}$ $(270 \mathrm{nmol} / 1)$, while their excretion in urine varied from 953 to $17800 \mu \mathrm{g} / 24 \mathrm{~h} \mathrm{(3193} \mathrm{to} 60028 \mathrm{nmol} / 24 \mathrm{~h}$; Adlercreutz et al. 1993b). In plasma an ENL concentration of up to $1 \mu \mathrm{mol} / 1$ can be regarded as physiological. The lignan concentration measured in plasma of vegetarians when compared with plasma levels of quercetin glucosides and catechins after a large supplementary meal, although lower, is of the same magnitude.

Although most investigators report beneficial properties of tea flavonoids and catechins (Stich, 1991) flavanols appear to have multiple, occasionally harmful effects such as induction of double-strand DNA breaks, DNA adducts, mutations and chromosome abberations in a great variety of test systems. Simultaneously, some workers have demonstrated pro-oxidant activity of flavonoids in short-term bacterial and mammalian systems under aerobic conditions, of which quercetin was the most potent (Nagao et al. 1979 , 1981; Myara et al. 1993). Such properties of lignans and isoflavonoids have not been reported. Actually, there is no evidence in the literature suggesting that phyto-oestrogens, present in such amounts in human food that they could have biological effects, are able to initiate cancer or stimulate already existing cancer. There seems to be no evidence that intake of lignans from tea and coffee, or other foods, may cause toxic or negative effects in human subjects (Welshons et al. 1987; Adlercreutz \& Mazur, 1997).

Lignan-containing plants have been used for centuries in folklore medicine for the treatment of all kinds of diseases including cancer (Ayres \& Loike, 1990). The lignans have antioxidative properties (Adlercreutz, 1990; Ayres \& Loike, 1990; Fauré et al. 1990) and are important antioxidants in plants. A possible preventive effect of lignans with regard to CHD has been discussed (Fauré et al. 1990) but not from this point of view.

We conclude that in addition to high levels of flavanols and flavones as well as some other polyphenols, we have for the first time detected and quantitatively determined MAT and SECO in tea in relatively high concentrations and in lower concentrations in coffee. In addition, we found small amounts of isoflavonoids in green tea and coffee. Tea intake belongs to the oldest traditions in many countries and its consumption is frequently high. Therefore, tea must be a significant contributor to the relatively high plasma levels of lignans in human plasma and urine. The lignan precursors from tea, or after conversion to the mammalian lignans in the gut, seem to have a number of biological properties making them candidates for a role as factors lowering risk of CHD and cancer (Adlercreutz et al. 1993a; Clarkson et al. 1995; Adlercreutz \& Mazur, 1997). Recent findings indicate that the levels of lignans in the human organism are higher than judged from analysis of the two identified precursors SECO and MAT in the diet (Adlercreutz \& Mazur, 1997). This discrepancy calls for further investigation of lignans in food and their absorption, metabolism and mechanisms of action in man.

\section{Acknowledgements}

We thank Ms Adile Samaletdin and Ms Sirkka Adlercreutz for skilful technical assistance. The method development and synthesis of standards and deuterium-labelled compounds was supported by NIH grants no. 1 R01 CA5628901 and no. 2 R01 CA 56289-04 and the analytical work by the EU research contract FAIR-CT95-0894.

\section{References}

Adlercreutz H (1990) Western diet and Western diseases: some hormonal and biochemical mechanisms and associations. Scandinavian Journal of Clinical and Laboratory Investigation 50, Suppl. 201, 3-23.

Adlercreutz H, Carson M, Palotie A, Booms S, Loukovaara M, Mäkelä T, Wähälä K, Brunow G \& Hase T (1993a) Lignans and isoflavonoids of dietary origin and hormone-dependent cancer. In Food and Cancer Prevention: Chemical and Biological Aspects, pp. 349-352 [KW Waldron, IT Johnson and GR Fenwick, editors]. Cambridge: The Royal Society of Chemistry. 
Adlercreutz H, Fotsis T, Bannwart $\mathrm{C}$, Wähälä $\mathrm{K}$, Brunow G \& Hase T (1991) Isotope dilution gas chromatographic-mass spectrometric method for the determination of lignans and isoflavonoids in human urine, including identification of genistein. Clinica Chimica Acta 199, 263-278.

Adlercreutz H, Fotsis T, Heikkinen R, Dwyer JT, Woods M, Goldin BR \& Gorbach SL (1982) Excretion of the lignans enterolactone and enterodiol and of equol in omnivorous and vegetarian women and in women with breast cancer. Lancet 2 , 1295-1299.

Adlercreutz H, Markkanen H \& Watanabe S (1993b) Plasma concentrations of phyto-oestrogens in Japanese men. Lancet 342, 1209-1210.

Adlercreutz H \& Mazur W (1997) Phytoestrogens and Western diseases (review). Annals of Medicine 29, 95-120.

Ayres DC \& Loike JD (1990) Lignans. Chemical, Biological and Clinical Properties. Cambridge: Cambridge University Press.

Brown CA, Bolton-Smith C, Woodward M \& Tunstall-Pedoe $\mathrm{H}$ (1993) Coffee and tea consumption and the prevalence of coronary heart disease in men and women: results from the Scottish heart study. Journal of Epidemiology and Community Health 47, 171-175.

Clarkson TB, Anthony MS \& Hughes CL (1995) Estrogenic soybean isoflavones and chronic disease - risks and benefits. Trends in Endocrinology and Metabolism 6, 11-16.

Fauré M, Lissi E, Torres R \& Videla LA (1990) Antioxidant activities of lignans and flavonoids. Phytochemistry 29, 37733775

Finlay EMH, Wilson DW, Adlercreutz H \& Griffiths K (1991) The identification and measurement of 'phyto-oestrogens' in human saliva, plasma, breast aspirate or cyst fluid, and prostatic fluid using gas chromatography-mass spectrometry. Journal of Endocrinology 129, Suppl., 49 Abstr.

Fotsis T \& Adlercreutz H (1987) The multicomponent analysis of estrogens in urine by ion exchange chromatography and GC-MS-I. Quantitation of estrogens after initial hydrolysis of conjugates. Journal of Steroid Biochemistry 28, 203213.

Gao YT, Mclaughlin JK, Blot WJ, Ji BT, Dai Q \& Fraumeni JF (1994) Reduced risk of esophageal cancer associated with green tea consumption. Journal of the National Cancer Institute 86, 855-858.

Goldbohm RA, Hertog MGL, Brants HAM, van Poppel G \& van den Brandt PA (1996) Consumption of black tea and cancer risk: a prospective cohort study. Journal of the National Cancer Institute 88, 93-100.

Graham HN (1992) Green tea composition, consumption, and polyphenol chemistry. Preventive Medicine 21, 334-350.

Green MS \& Harari G (1992) Association of serum lipoproteins and health-related habits with coffee and tea consumption in free-living subjects examined in the Israeli CORDIS study. Preventive Medicine 21, 532-545.

Gugler R, Leschik M \& Dengler HJ (1975) Disposition of quercetin in man after single oral and intravenous doses. European Journal of Clinical Pharmacology 9, 229-234.

Heilbrun LK, Nomura A \& Stemmermann GN (1986) Black tea consumption and cancer risk: a prospective study. British Journal of Cancer 54, 677-683.

Hertog MGL, Feskens EJM, Hollman PCH, Katan MB \& Kromhout D (1993a) Dietary antioxidant flayonoids and risk of coronary heart disease - the Zutphen elderly study. Lancet 342, 1007-1011.

Hertog MGL, Hollman PCH \& Vandeputte B (1993b) Content of potentially anticarcinogenic flavonoids of tea infusions, wines, and fruit juices. Journal of Agriculture and Food Chemistry 41, 1242-1246.
Hirose M, Hoshiya T, Akagi K, Takahashi S, Hara Y \& Ito N (1993) Effects of green tea catechins in a rat multi-organ carcinogenesis model. Carcinogenesis 14, 1549-1553.

Ho C-T, Chen Q, Shi H, Zhang K-Q \& Rosen RT (1992) Antioxidative effect of polyphenol extract prepared from various Chinese teas. Preventive Medicine 21, 520525 .

Hollman PCH, Devries JHM, Vanleeuwen SD, Mengelers MJB \& Katan MB (1995) Absorption of dietary quercetin glycosides and quercetin in healthy ileostomy volunteers. American Journal of Clinical Nutrition 62, 1276-1282.

Hollman PCH, Gaag MVD, Mengelers MJB, Trijp JMP, de Vries JHM \& Katan MB (1996) Absorption and disposition kinetics of the dietary antioxidant quercetin in man. Free Radical Biology and Medicine 21, 703-707.

Horvat RJ \& Senter SD (1980) A gas-liquid chromatographic method for analysis of phenolic acids in plants. Journal of Agriculture and Food Chemistry 28, 1292-1295.

Hu GZ, Han C \& Chen J (1995) Inhibition of oncogene expression by green tea and $(-)$-epigallocatechin gallate in mice. Nutrition and Cancer 24, 203-209.

Imai K \& Nakachi K (1995) Cross sectional study of effects of drinking green tea on cardiovascular and liver diseases. British Medical Journal 310, 693-696.

Jain AK, Shimoi K, Nakamura Y, Kada T, Hara Y \& Tomita I (1989) Crude tea extracts decrease the mutagenic activity of $\mathrm{N}$ methyl- $\mathrm{N}^{\prime}$-nitro-N-nitrosoguanidine in vitro and in intragastric tract of rats. Mutation Research 210, 1-8.

Jordan VC, Koch R \& Bain RR (1985) Prolactin synthesis by cultured rat pituitary cells: an assay to study estrogens, antiestrogens and their metabolites in vitro. In Estrogens and the Environment II. Influences and Development, pp. 221-234 [JA McLachlan, editor]. New York: Elsevier.

Katiyar SK, Agarwal R, Wang ZY, Bhatia AK \& Mukhtar H (1992) (-)-Epigallocatechin-3-gallate in Camellia sinensis leaves from Himalayan region of Sikkim: inhibitory effects against biochemical events and tumor initiation in Sencar mouse skin. Nutrition and Cancer 18, 73-83.

Katiyar SK \& Mukhtar H (1996) Tea in chemoprevention of cancer: epidemiologic and experimental studies (review). International Journal of Oncology 8, 221-238.

Kinlen LJ, Willows AN, Goldblatt P \& Yudkin J (1988) Tea consumption and cancer. British Journal of Cancer 58, 397401.

Klaunig, JE (1992) Chemopreventive effects of green tea components on hepatic carcinogenesis. Preventive Medicine 21, 510-519.

Kohlmeier L, Weterings KGC, Steck S \& Kok FJ (1997) Tea and cancer prevention: an evaluation of the epidemiologic literature. Nutrition and Cancer 27, 1-13.

Kono S (1992) Green tea and colon cancer. Japanese Journal of Cancer Research 83, 669.

La Vecchia C, Negri E, Franceschi S, Davanzo B \& Boyle P (1992) Tea consumption and cancer risk. Nutrition and Cancer 17, 27-31.

Lee M-J, Wang Z-Y, Li H, Chen L, Sun Y, Gobbo S, Balentine DA \& Yang CS (1995) Analysis of plasma and urinary tea polyphenols in human subjects. Cancer Epidemiology, Biomarkers and Prevention 4, 393-399.

Mazur W, Fotsis T, Wähälä K, Ojala S, Salakka A \& Adlercreutz $H$ (1996) Isotope dilution gas chromatographic-mass spectrometric method for the determination of isoflavonoids, coumestrol, and lignans in food samples. Analytical Biochemistry 233 , $169-180$

Morton MS, Matosferreira A, Abranchesmonteiro L, Correia R, Blacklock N, Chan PSF, Cheng C, Lloyd S, Chiehping W \& Griffiths K (1997) Measurement and metabolism of isofiavo- 
noids and lignans in the human male. Cancer Letters 114, 145151.

Mousavi Y \& Adlercreutz H (1992) Enterolactone and estradiol inhibit each other's proliferative effect on MCF-7 breast cancer cells in culture. Journal of Steroid Biochemistry and Molecular Biology 41, 615-619.

Mukhtar H, Wang ZY, Katiyar SK \& Agarwal R (1992) Tea components: antimutagenic and anticarcinogenic effects. Preventive Medicine 21, 351-360.

Myara I, Pico I, Vedie B \& Moatti N (1993) A method to screen for the antioxidant effect of compounds on low-density lipoprotein (LDL) - illustration with flavonoids. Journal of Pharmacological and Toxicological Methods 30, 69-73.

Nagao M, Morita N, Yahagi T, Shimizu M, Kuroyanagi M, Fukuoka, M, Yoshihira, K, Natori, S, Fujino, T \& Sugimura, T (1981) Mutagenicities of 61 flavonoids and 11 related compounds. Environmental Mutagenesis 3, 401-419.

Nagao M, Takahashi Y, Yamanaka H \& Sugimur T (1979) Mutagens in coffee and tea. Mutation Research 68, 101-106.

Nanjo F, Honda M, Okishio K, Matsumoto N, Ishigaki F, Ishigami T \& Hara Y (1993) Effects of dietary tea catechins on alphatocopherol levels, lipid peroxidation, and erythrocyte deformability in rats fed on high palm oil and perilla oil diets. Biological and Pharmaceutical Bulletin 16, 1156-1159.

Paganga G \& Rice-Evans CA (1997) The identification of flavonoids as glycosides in human plasma. FEBS Letters 401, 78-82.

Sano M, Takahashi Y, Yoshino K, Shimoi K, Nakamura Y, Tomita I, Oguni I \& Konomoto H (1995) Effect of tea (Camellia sinensis 1) on lipid peroxidation in rat liver and kidney: a comparison of green and black tea feeding. Biological and Pharmaceutical Bulletin 18, 1006-1008.

Setchell KDR, Lawson A M, Borriello SP, Harkness R, Gordon H, Morgan DML, Kirk DN, Adlercreutz H, Anderson LC \& Axelson M (1981) Lignan formation in man - microbial involvement and possible roles in relation to cancer. Lancet 2 , 4-7.

Stehle G, Hinohara S, Cremer P, Feng Z, Bernhardt R, Goto Y, Seidel D, Heene DL \& Schettler G (1991) Differences in the risk factor patterns for coronary heart disease in China, Japan, and Germany. Klinische Wochenschrift 69, 629-632.
Stensvold I, Tverdal A, Solvoll K \& Foss OP (1992) Tea consumption. Relationship to cholesterol, blood pressure, and coronary and total mortality. Preventive Medicine 21, 546-553.

Stich HF (1991) The beneficial and hazardous effects of simple phenolic compounds. Mutation Research 259, 307-324.

Stich HF (1992) Teas and tea components as inhibitors of carcinogen formation in model systems and man. Preventive Medicine 21, 377-384.

Vinson JA, Dabbagh YA, Serry MM \& Jang JH (1995) Plant flavonoids, especially tea flavonols, are powerful antioxidants using an in vitro oxidation model for heart disease. Journal of Agricultural and Food Chemistry 43, 2800-2802.

Wang ZY, Agarwal R, Khan WA \& Mukhtar H (1992) Protection against benzo[a]pyrene- and $\mathrm{N}$-nitrososdiethylamine-induced lung and forestomach tumorigenesis in $\mathrm{A} / \mathrm{J}$ mice by water extracts of green tea and licorice. Carcinogenesis 13, 14911494.

Wang ZY, Cheng SJ, Zhou ZC, Athar M, Khan WA, Bickers DR \& Mukhtar A (1989) Antimutagenic activity of green tea polyphenols. Mutation Research 223, 273-285.

Wang ZY, Huang MT, Lou YR, Xie JG, Reuhl KR, Newmark HL, Ho CT, Yang CS \& Conney AH (1994) Inhibitory effects of black tea, green tea, decaffeinated black tea, and decaffeinated green tea on ultraviolet $b$ light-induced skin carcinogenesis in 7,12-dimethylbenz[a]anthracene-initiated SKH-1 mice. Cancer Research 54, 3428-3435.

Waters AP \& Knowler JT (1982) Effect of a lignan (HPMF) on RNA synthesis in the rat uterus. Journal of Reproduction and Fertility 66, 379-381.

Welshons WV, Murphy CS, Koch R, Calaf G \& Jordan VC (1987) Stimulation of breast cancer cells in vitro by the environmental estrogen enterolactone and the phytoestrogen equol. Breast Cancer Research and Treatment 10, 169-175.

Yoshino K, Hara Y, Sano M \& Tomita I (1994) Antioxidative effects of black tea theaflavins and thearubigin on lipid peroxidation of rat liver homogenates induced by tert-butyl hydroperoxide. Biological and Pharmaceutical Bulletin 17, 146-149.

Young W, Hotovec RL \& Romero AG (1967) Tea and atherosclerosis. Nature 216, 1015-1016. 